\title{
Article \\ Employer's Information Requirements: A Case Study Implementation of BIM on the Example of Selected Construction Projects in Poland
}

\author{
Krzysztof Zima and Ewelina Mitera-Kiełbasa * (D) \\ Division of Management in Civil Engineering, Tadeusz Kościuszko Cracow University of Technology, \\ 24 Warszawska Street, 31-155 Cracow, Poland; krzysztof.zima@pk.edu.pl \\ * Correspondence: e.mitera@pk.edu.pl
}

check for

updates

Citation: Zima, K.; Mitera-Kiełbasa,

E. Employer's Information

Requirements: A Case Study

Implementation of BIM on the

Example of Selected Construction

Projects in Poland. Appl. Sci. 2021, 11,

10587. https://doi.org/10.3390/

app112210587

Academic Editors: Karolina Ogrodnik and Beata Sadowska

Received: 3 October 2021

Accepted: 3 November 2021

Published: 10 November 2021

Publisher's Note: MDPI stays neutral with regard to jurisdictional claims in published maps and institutional affiliations.

Copyright: (c) 2021 by the authors. Licensee MDPI, Basel, Switzerland. This article is an open access article distributed under the terms and conditions of the Creative Commons Attribution (CC BY) license (https:// creativecommons.org/licenses/by/ $4.0 /)$.
Abstract: Case studies available in the literature clearly point to the numerous benefits of BIM (Building Information Modeling), in addition to the barriers that participants of such projects may face. This paper is a case study of Employer's Information Requirements (EIR) for preparing and managing BIM models in the design and construction of selected large public construction projects: the Cogiteon Lesser Poland Science Center (LPSC Cogiteon), the Krakow Music Center (KMC) and the Copernican Revolution Studio (CRS). The paper presents the main aspects included in EIRs. It discusses the technical (e.g., requirements for the Common Data Environment platform-CDE), management (including the scopes of responsibility of staff in charge of BIM) and strategic sections (primary expectations concerning Data Drops) of the EIR. Projects executed using BIM by public institutions allow for the application of insight gained as a result of their completion and the creation of a knowledge base or checklist for future projects. The projects discussed here, carried out using advanced BIM solutions, could potentially be developed further by the proposed content extension concerning levels of detail (this paper cites potential guidelines that can be applied), component elements concerning price and qualifications, so as to easily generate bills of costs, and information used in facility management which can also encourage facility manager cooperation. Examples of EIR provisions are presented based on an analysis of three completed construction projects carried out using advanced BIM solutions. BIM is still a new form of management and this paper expands the range of available EIR standards, in addition to presenting guidelines for their practical application in the construction industry.

Keywords: BIM; EIR employer's information requirements; CDE common data environment

\section{Introduction}

Building Information Modeling (BIM) is "the process of generating, storing, managing, exchanging and sharing building information in an interoperable and reusable way" [1] with the use of BIM models. Construction project execution using BIM can bring measurable benefits in the form of lower costs over a building's life cycle [2-4], a shorter construction completion time due to less design errors [5,6] and less wastefulness [7]. A report by the Boston Consulting Group suggests that by 2025, due to the application of a wide-ranging digitalization process, yearly global savings during the design, engineering and construction stages will amount to $13-21 \%$, and savings during the operation phase will amount to $10-17 \%$ [8]. Some countries have introduced programs and government regulations on BIM implementation, thereby encouraging developers to adopt it [9]. In some countries, BIM implementation is highly developed, while in others it is only starting to be introduced [4,10-14]. In Poland, projects that utilize BIM, especially during the construction phase [15], are relatively uncommon, yet their number is expected to increase [16]. Education in BIM contributes to the construction sector's productivity [17]. The results of surveys among students encourage the mandatory teaching of BIM [18]. Due to the benefits 
of education in BIM, certain universities have incorporated it into their curricula [19-21]. The number of research papers and presentations delivered at national and international conferences dedicated to BIM is growing [22,23]. To investors, the availability of BIM tools [24-26], including data exchange platforms between stakeholders, called Common Date Environment CDE [27,28], integrated management principles based on BIM models in the building [29-31], case studies (e.g., [32-34]) and execution standards [9,35,36] can facilitate starting a project using BIM. As stipulated in the ISO 19650 standard [37], in the context of information management, a building's life cycle consists of three essential parts: Organizational Management, e.g., following ISO 9001, Asset and Project Management following ISO 55000 [38] and ISO 21500 [39], and Information Management following ISO 19650 [37]. The last of these phases consists of a cycle between the Delivery Phase PIM and the Operational Phase AIM, which ensures that information obtained during project execution is used during the building's operation. During the first stage of real estate development, the developer should formulate organizational goals and requirements, and specify what information they will require from other project participants. These guidelines, which are made available to stakeholders, are called Exchange Information Requirements or Employer's Information Requirements, and concern information exchange while accounting for the Ordering Party's goals, execution standards, processes and what is expected of project participants. They can also describe the manner of delivering documentation and its content. The Requirements are an essential document in the development process. Their highly precise formulation is crucial, as it determines what will be required later so as to avoid disappointment with the end result [40].

The correct formulation of the Employer's Information Requirements is difficult and complex [34,41,42]. The aim of our research is analysis of Employer's Information Requirements as based on selected large construction projects from Poland. The objective of the study was to facilitate EIR formulation for future construction projects using BIM.

\section{Materials and Methods}

From among public orders to be implemented using BIM technology, those which assumed complete execution using BIM were selected. Order documentation was then procured from the Public Information Bulletin [43] for this group. To present the greatest possible amount of EIR requirements in the paper, the requirements were grouped based on similarity. Afterwards, the function of buildings was confined to science centers, which was followed by only selecting requirements to be applied to design firms that were to prepare complete design documentation and secure relevant approvals and permits. As requirements formulated by the same developer are often similar, requirements for other orders by developers of science centers were analyzed from among the preselected group. Ultimately, a decision was made to present a case study of three EIRs: for the construction of the Lesser Poland Science Center (currently the Cogiteon Lesser Poland Science Center), the Krakow Music Center and the Copernican Revolution Studio in Warsaw, along with their site development and necessary underground infrastructure. The requirements analyzed concerned the design stage and specified regulations directly tied with managing the construction project and the application BIM application. A short overview of the projects has been presented in Table 1 .

To better illustrate the degree of complication of the buildings, their conceptual designs have been shown in Figure 1 below. 
Table 1. Brief overview of projects for which an analysis of Employer's Information Requirements was performed to the extent of BIM application.

\begin{tabular}{|c|c|c|c|}
\hline & $\begin{array}{c}\text { Copernican Revolution } \\
\text { Studio CRS }\end{array}$ & $\begin{array}{l}\text { Cogiteon Lesser Poland } \\
\text { Science Center LPSC }\end{array}$ & Krakow Music Center CM \\
\hline $\begin{array}{l}\text { Name of the EIR document } \\
\text { concerning BIM model } \\
\text { standards }\end{array}$ & $\begin{array}{l}\text { BIM Model Preparation } \\
\text { Standards }\end{array}$ & $\begin{array}{c}\text { Ordering Party's } \\
\text { Informational Requirements } \\
\text { on BIM Model Standards }\end{array}$ & $\begin{array}{c}\text { Ordering Party's } \\
\text { Informational Requirements } \\
\text { on BIM Model Standards }\end{array}$ \\
\hline $\begin{array}{l}\text { Year of publishing the public } \\
\text { order in which the EIR was } \\
\text { included }\end{array}$ & 2017 & 2017 & 2018 \\
\hline Building category & Public building & Public building & Public building \\
\hline $\begin{array}{l}\text { Additional developer } \\
\text { requirements }\end{array}$ & $\begin{array}{l}\text { A building that includes a } \\
\text { multi-functional space that is } \\
\text { easy to modify, } \\
\text { energy-efficient, equipped } \\
\text { with proenvironmental } \\
\text { solutions }\end{array}$ & $\begin{array}{l}\text { Innovative and model } \\
\text { building, an example of } \\
\text { sustainable architecture }\end{array}$ & $\begin{array}{l}\text { Building with concert halls } \\
\text { with the highest degree of } \\
\text { acoustic comfort }\end{array}$ \\
\hline Usable floor area & $4400 \mathrm{~m}^{2}$ & $14,098.06 \mathrm{~m}^{2}$ & Design stage ongoing \\
\hline Estimated value & Ca. 17.7 million euro & Ca. 35.4 million euro & Ca. 58.7 million euro \\
\hline Planned handover & 2022 & 2023 & 2024 \\
\hline $\begin{array}{c}\text { Current project stage (as of } \\
27.07 .2021 \text { ) }\end{array}$ & Construction stage & Construction stage & $\begin{array}{c}\text { Project paused at the stage of } \\
\text { signing a contract with a } \\
\text { design firm, design } \\
\text { competition concluded. }\end{array}$ \\
\hline
\end{tabular}

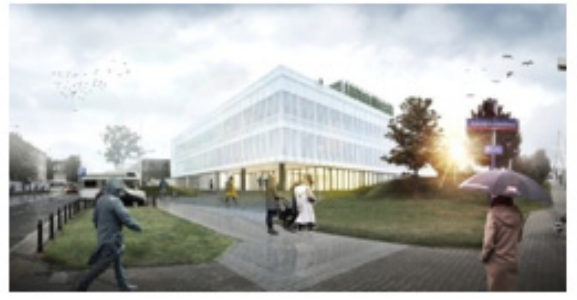

(a)

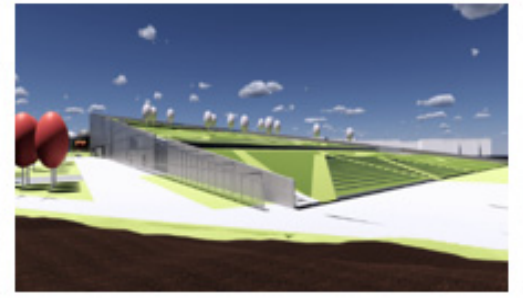

(b)

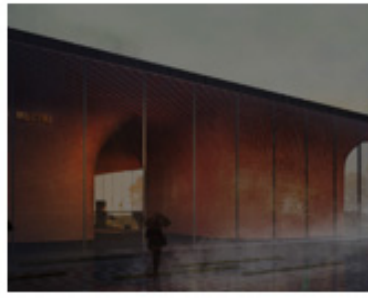

(c)

Figure 1. Conceptual designs of (a) the Copernican Revolution Studio; (b) the Cogiteon Lesser Poland Science Center; (c) the Krakow Music Center. Sources: (a) [44]; (b) [45]; (c) [46].

\section{Results}

The Employer's Information Requirements were divided into thematic fields as presented in Table 2. The names of areas were taken from Polish BIM standards [47] due to there being little difference in area naming in the EIRs for the LPSC, KMC and CRS.

Table 2. Comparison of the fields and appendices of Employer's Information Requirements (EIR) concerning BIM model preparation for the Cogiteon Lesser Poland Science Center, the Krakow Music Center and the Copernican Revolution Studio, Original work based on EIR for the LPSC, KMC and CRS.

\begin{tabular}{ccc}
\hline Field & $\begin{array}{c}\text { For the Cogiteon Lesser Poland Science Center } \\
\text { and the Krakow Music Center }\end{array}$ & For the Copernican Revolution Studio \\
\hline & Software platforms & Sata exchange formats \\
Units and coordinates & Data exchange \\
Technical aspects & Coordinates \\
& $\begin{array}{c}\text { General recommendations on levels of detail, levels } \\
\text { of detail for each specialization and stage } \\
\text { Training courses } \\
\text { Standards }\end{array}$ & Levels of detail \\
& Standards \\
\hline
\end{tabular}


Table 2. Cont.

\begin{tabular}{|c|c|c|}
\hline Field & $\begin{array}{c}\text { For the Cogiteon Lesser Poland Science Center } \\
\text { and the Krakow Music Center }\end{array}$ & For the Copernican Revolution Studio \\
\hline \multirow{7}{*}{ Management } & File naming and folder structure conventions & $\begin{array}{c}\text { File naming protocol, design information } \\
\text { management system }\end{array}$ \\
\hline & Participant roles and responsibility scopes & Task scopes and responsibilities \\
\hline & Model and documentation management & Task planning \\
\hline & Data security & Data security \\
\hline & Coordination and clash detection & $\begin{array}{l}\text { Coordination rules and clash detection, } \\
\text { coordination scope }\end{array}$ \\
\hline & & Means of data transfer \\
\hline & Meetings and model reviews & \\
\hline \multirow{5}{*}{ Strategic } & Data drops, work and data drop planning & \\
\hline & Objectives & $\begin{array}{c}\text { Objectives, Ordering Party's strategic } \\
\text { objectives }\end{array}$ \\
\hline & $\begin{array}{l}\text { Scope of models, 2D documentation and tables, 3D } \\
\text { model, geometric data, } 4 \mathrm{D} \text { models schedule } \\
\text { 5D model bill of costs, } \\
\text { 6D model, energy analyses, comfort of use }\end{array}$ & $\begin{array}{l}\text { Building elements, requirement concerning } \\
\text { geometric and non-geometric information, } \\
\text { 2D documentation, bill of costs }\end{array}$ \\
\hline & Contractor competences ${ }^{1}$ & Competences \\
\hline & Revisions & Documentation revisions \\
\hline Appendices & $\begin{array}{c}\text { Index of terms, } \\
\text { Level of detail definitions, } \\
\text { Component levels of detail for each stage, } \\
\text { Component list, data drops and stages, process } \\
\text { diagram, versions, revision and version suitability } \\
\text { codes compliant with BS 1192:2007 + A2:2016 }\end{array}$ & $\begin{array}{l}\text { Abbreviations and terms, data structure plan, } \\
\text { building elements, definition level, data } \\
\text { delivery tables, room and net floor area } \\
\text { schedules, } \\
\text { roles and responsibilities, } \\
\text { BIM process, } \\
\text { data transfer schedule }\end{array}$ \\
\hline
\end{tabular}

${ }^{1}$ as understood by the contractor.

\section{Discussion}

\subsection{The Technical Field}

The projects analyzed were public commissions, which cannot limit contractors to the use of products by specific manufacturers by Polish law. The project guidelines noted that the models should be saved, also in native formats and in the open $2 \times 3$ IFC (Industry Foundation Classes) format, which is open. This allows for opening models using freeware model viewers, such as xBIM Xplorer, DDS-CAD OpenBIM Viewer, BIM Surfur, Solibri Model Viewer and BIM Vision [24], without forcing a user to purchase the software used to make the models.

The requirements also discussed the communications platform that project participants were to use. The Common Data Environment (CDE), also called a Coordination Platform, typically consists of cloud-based software or a shared server. Thus, the Ordering Party should specify how many users are to use this platform and for how long, and during a later stage, what privileges they are to have (e.g., saving, making revisions). This allows the Ordering Party, via a bidding procedure, to estimate future costs, including software purchases. The requirements should also specify what the platform is to be used for. In the case of the EIRs for the LPSC and KMC, it was stipulated that, apart from enabling model browsing, the saving of other files such as those concerning institutional approvals, there should was also to be an option to add comments and timestamps models. Properly defining CDE guidelines is a demanding task in light of its brief description in BIM standards, yet it is crucial as it can increase flexibility in the light of contingencies such as legislation and technical innovation [28]. A cloud-based platform or an external server bears the risk of unwanted user intrusion, which is why data safety should be a priority when writing an EIR. It would be favorable to either propose one's own solution or clearly stipulate that the contractor is to specify it. This element was included in the guidelines of the LPSC, 
the KMC and the CRS. To avoid data loss, both the design team and the developer's team should make regular copies while complying with data confidentiality requirements.

A parametric model of a building built using BIM, apart from enabling the generation of drawings needed to file for applicable permits, choose a contractor and for actual construction, can also be used during a building's use along with previously entered data. To this end, non-graphical data should be saved, for instance in COBie format (Construction Operations Building Information Exchange, example presented in Figure 2), which can be used throughout a building's entire life cycle.

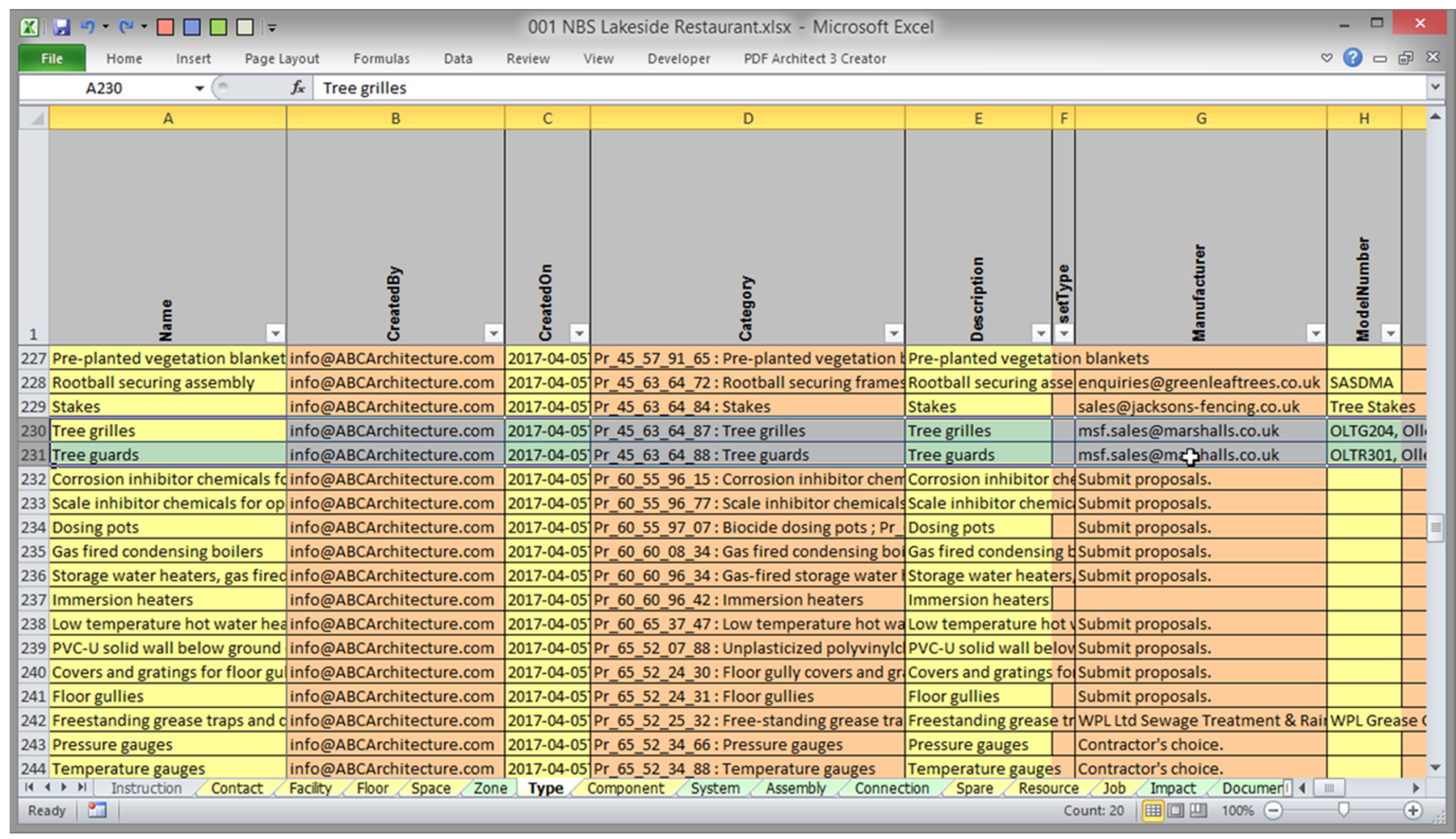

Figure 2. Example of COBie sheet. Source: [48].

The necessity to save non-graphical data in COBie format in a SpreadsheetML version, which can be used by MS Office software, was mentioned in the EIR for the LPSC and KMC.

The guidelines also included required training in software necessary for project execution that the design firm should provide for a group from the developer's team specified in the EIR. The EIR also specified the preferred metric units, coordinates (for the LPSC and KMC, the indications were PUWG PL2000 zone 7, PPK PL-2000, zone 6 and coordinates based on the EUREF-89 reference system), and the necessity to define a base reference point by the design firm. Another essential document in carrying out a construction project using BIM is the BIM Execution Plan (BEP), which is a detailed plan approved by the developer that extends an EIR's guidelines. The BEP is prepared by the contractor (in the cases analyzed these were design firms) and should be accepted by the developer prior to contract signature, as it is to be an appendix to the contract. This is how it functioned in the projects under study.

Defining the level of detail (LOD) for geometric data and the Level of Information (LOI) for non-geometric data is an important component of an EIR's technical field. These levels depend on the project stage, i.e., whether it is conceptual, technical or a detailed handover design. The developer, by specifying in the EIR the expected, even general level of detail, minimizes the possibility of disappointment with the precision of the finished design. The designer, in agreement with the developer, has a greater motivation to introduce revisions 
and analyze alternatives at a stage with a low level of detail, as there are less data to modify [49]. Definitions and specific levels of detail for model elements differ depending on guidelines. For instance, British guidelines featured in the PAS-1192-2-2013 [50] Level of Definition were divided into those that concern the Level of Detail (LOD) for geometric data and the Level of Information (LOI) for non-geometric data, with a seven-grade scale from 1 to 7 . A document published by BIMForum also introduced the Level of Development (LOD [51], which is described as a broader term than Level of Detail, but that does not divide the scale into geometric and non-geometric data. The Level of Development consists of a six-level scale, from 100 to 500, with level 350 applying to the joints between elements, supports and level 500 referencing only non-geometric data (field verification). The ISO 19650 standard [37] introduced the broad Level of Information Need. In Polish standard proposals compliant with the PN-EN ISO 19650 standard [52], a five-level scale of 1 to 5 was proposed, describing levels for the following categories: Level of Graphical Detail (LOgD), the Level of Model Information (LOmI), coordination (application in 3D), work schedule (implemented in 4D), bills of quantities and costs (implemented in 5D) and facility management (implemented in 6D) [47]. For road engineering projects, a five-level division was proposed, from 1 to 5 , similarly to the British guidelines, with a division into geometric and non-geometric data, based on the example of bridge construction [53]. There is also another Polish proposal [54], yet it is too general in terms of levels of detail/development or references other standards.

The levels of detail presented in Table 3 are general guidelines that can differ for each model component. For instance, rebar geometric data (e.g., whether ribs are to be visible) can be less detailed than data for sanitary equipment (e.g., sinks, bathroom fittings). Thus, the design firm should specify the planned levels of detail for each element type in the BEP. In the appendices to the EIRs of the LPSC, the KMC and the CRS, this specification was a table of sample design elements, and definitions of levels of detail were also featured in the EIRs of the LPSC and the KMC. The contractor can propose their own LOD definitions or use existing ones. In the projects under study, design firms proposed levels of detail and their definitions. After their approval by the developer, they were included in the BEP prior to signing the contract for preparing comprehensive design documentation. The definitions of LODs proposed in the EIRs for the LPSC and KMC are presented in Table A1 in Appendix A.

Table 3. Levels of Detail (LOD) and Levels of Information (LOI) for the Cogiteon Lesser Poland Science Center (LPSC), the Krakow Music Center (KMC) and the Copernican Revolution Studio (CRS). Original work based on EIRs for the LPSC, the KMC and the CRS.

\begin{tabular}{lcccc}
\hline & \multicolumn{2}{c}{ Level of Detail LOD } & Level of Information LOI \\
\hline & \multicolumn{2}{c}{ For the CRS } & $\begin{array}{c}\text { For the LPSC } \\
\text { and the KMC }\end{array}$ & $\begin{array}{c}\text { For the LPSC } \\
\text { and the KMC }\end{array}$ \\
\hline Conceptual design & To be proposed by the designer & 3 & To be proposed by the designer & 3 \\
\hline Technical design $^{1}$ & To be proposed by the designer & 4 & To be proposed by the designer \\
\hline Detailed design $^{1}$ & To be proposed by the designer & 5 & To be proposed by the designer & 5 \\
\hline $\begin{array}{l}{ }^{1} \text { In Poland, to obtain a building permit, one must submit an architectural and construction design to the relevant administration. The } \\
\text { technical design, which corresponds to a detailed design, is a more precise version of the architectural and construction design. }\end{array}$
\end{tabular}

\subsection{The Management Field}

The description of standards for communications between project participants and data safety was to be prepared entirely by contractors in the BEP, as specified in the EIR. The BEP should also feature file naming conventions, the folder structure and the file versioning system. These principles should apply to all project participants, as well as to the contractors of the design firm whose documentation will be placed in the CDE. 
In the EIRs for the LPSC and the KMC, the developer stipulated that meetings with the design team were to take place at the latter's facilities at predetermined dates. Thus, it fell to the design team to provide the equipment necessary to review the model.

To create, manage and coordinate BIM models and the CDE platform, one needs personnel with suitable qualifications. In the EIRs for the LPSC and the KMC, the BEP was to feature a list of staff members and their roles and scopes of responsibility. In the LPSC guidelines, the following aspects of the BIM process and models were listed:

- Model creation;

- Model coordination;

- Coordination of the entire BIM delivery process;

- Access and information sharing management;

- Providing levels of detail suitable for each stage and component.

The EIR for the CRS presented a table with the scope of responsibility for persons in charge of BIM model management, wherein the BIM coordinator was the person responsible for detecting clashes and coordinating models, while the information manager was a person from the developer's team, in charge of managing information in BIM (data safety and exchange, model supervision, compliance control), as featured in Table 4.

Table 4. Fragment of an appendix to the EIR of the Copernican Revolution Studio on scopes of responsibility.

\begin{tabular}{|c|c|c|c|c|c|c|c|c|}
\hline Duties & 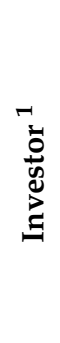 & 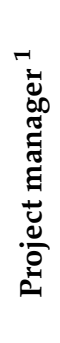 & 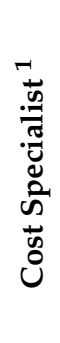 & 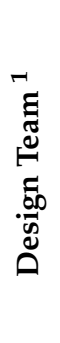 & 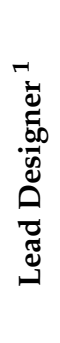 & 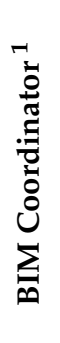 & 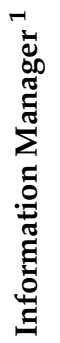 & 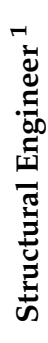 \\
\hline \multicolumn{9}{|c|}{ CDE-Common Data Environment } \\
\hline CDE consulting & $\mathrm{Z}$ & $\mathrm{I}$ & & & & K & $\mathrm{O}$ & \\
\hline CDE provision & $\mathrm{O}$ & $\mathrm{I}$ & $\mathrm{I}$ & I & $\mathrm{I}$ & $\mathrm{I}$ & I & I \\
\hline CDE configuration & $\mathrm{Z}$ & K & $\mathrm{K}$ & K & K & K & K & K \\
\hline CDE maintenance & & K & & I & $\mathrm{K}$ & K & $\mathrm{O}$ & \\
\hline $\begin{array}{l}\text { Downloading/uploading the entire information design to/from } \\
\text { the CDE }\end{array}$ & $\mathrm{O}$ & $\mathrm{O}$ & & $\mathrm{O}$ & $\mathrm{O}$ & $\mathrm{O}$ & $\mathrm{O}$ & $\mathrm{O}$ \\
\hline \multicolumn{9}{|c|}{$\begin{array}{ll} & \text { Quality and control assurance } \\
\end{array}$} \\
\hline Compliance with procedures included in the BIM model standard & & & & $\mathrm{O}$ & $\mathrm{O}$ & & & $\mathrm{O}$ \\
\hline Report on budget changes, cost and design & $\mathrm{Z}$ & & $\mathrm{O}$ & & & & & $\mathrm{O}$ \\
\hline $\begin{array}{l}\text { Testing and coordination of virtual model, including full clash } \\
\text { detection as featured in relevant BIM software }\end{array}$ & & I & & K & $\mathrm{O}$ & & & $\mathrm{O}$ \\
\hline $\begin{array}{l}\text { Report on the overall model quality in terms of geometry, essentials } \\
\text { and data }\end{array}$ & & I & & & & & $\mathrm{O}$ & \\
\hline $\begin{array}{l}\text { Report on BEP compliance in terms of LOD, completeness and BIM } \\
\text { model standards }\end{array}$ & & I & & & & I & $\mathrm{O}$ & \\
\hline Report on 4D and 5D model functionality, as used by other designers & & I & K & & & $\mathrm{O}$ & $\mathrm{K}$ & \\
\hline Review of data received for compliance with the EIR & & & & $\mathrm{O}$ & $\mathrm{O}$ & & $\mathrm{O}$ & $\mathrm{O}$ \\
\hline Risk assessment report filing & & I & & K & K & & I & K \\
\hline $\begin{array}{l}\text { Support for the lead designer by the team in 3D model coordination. } \\
\text { Clash detection }\end{array}$ & & I & & $\mathrm{K}$ & $\mathrm{O}$ & & & K \\
\hline
\end{tabular}

\footnotetext{
${ }^{1}$ duty and function symbols: O-responsible; performs task; Z-approves; K-consults; I-informed.
} 
In construction projects executed with the use of BIM, persons with BIM process qualifications should be present on both sides, namely on the developer's side so as to properly verify the information delivered, and on the contractor's side

In a study on construction wastefulness, Polish contractors typically indicated design documentation errors and inconsistencies as having the greatest impact on project cost and completion time [55], which is why coordinating this documentation is so important. Process stages associated with model coordination can be defined in an EIR.

Certain clashes, prior to their removal, should be consulted with the developer. For instance, a revision proposed by the developer can lead to changes in a different, preapproved component, a change in the aesthetics of a room in which said element is to be located, a change in project cost and completion time, etc. In such a situation, the developer should know the consequences of the revision and thus make an informed decision. Such situations should be planned for in a EIR document, with relevant procedures laid out, or it should feature an annotation that such a procedure is to be proposed by the contractor after the developer's acceptance, and included in the BEP, which is a part of the contract.

In light of the above, the designer submits coordinated models with any clashes that do not need to be approved by the developer removed, as well as a clash report, while clashes that require Ordering Party approval are clearly presented for discussion. After the final version's acceptance, relevant changes are applied to the models, after which a new clash report is generated and submitted to the developer.

In the field under discussion, expectations concerning the models supplied were referenced, with an indication of the PUWG PL2000 zone 7 coordinate system, with a point of reference specified in the BEP. Only the necessary information was to be sent, with models divided by specialization and the possible geometric division of the integrated multi-specialization model, should the file be too large (in the CRS EIR, a specific stipulation states that files in excess of $100 \mathrm{MB}$ were to be divided into smaller ones).

\subsection{The Strategic Field}

The strategic field, labeled as "organizational requirements" in the case of the LPSC, KMC and CRS, lists expectations on data drops, models, as well as the necessity to indicate in the BEP any proposed procedures for introducing and approving revisions. The developer also reserved the right to assess the competence of the contractor in the field of BIM execution and EIR compliance solely after familiarization with the BIM Execution Plan.

According to the guidelines, the designer was obligated to submit data in compliance with the Data Drops (Table 5) to the developer, as stipulated in a schedule approved prior to contract signature, suitably to the stage of the documentation. The data in question mostly featured models, schedules, bills of costs and analyses.

The data supplied via Data Drops in accordance with the BEP schedule were to be verified for contract compliance, including the EIR appendix concerning BIM, and the level of advancement, by an Ordering Party representative. They were to be shared with persons in the developer's team for inspection and commentary, specifying the deadline for introducing any corrections and, most importantly, constituting approval of a given stage and signaling the start of the subsequent phase.

Models should be developed following the relevant LOD and LOI, jointly approved by the designer and developer, and only initially proposed by the developer (as mentioned earlier, certain elements do not need to be presented in high geometric detail for the information required by the developer, contractor or facility manager), at a date specified in the schedule and in the correct format. Two-dimensional data should be generated from models. The design should ensure that components feature sufficiently detailed information to allow for generating schedules relevant to the developer. Models should be divided by specialization; namely, apart from the architectural (the architectural BIM model for the LPSC is presented in Figure 3) and structural model, there should also be models for low-voltage utilities, fire safety, the compressed air systems and a central building 
management system (BMS) coupled with an energy management system (EMS). The EIR for the KMC also stipulated the development of an acoustic model.

Table 5. Data Drops from the EIR for the Krakow Music Center.

\begin{tabular}{|c|c|c|c|c|c|c|c|}
\hline \multirow[t]{2}{*}{ DD } & Stage & \multicolumn{4}{|c|}{ Model Objectives } & \multicolumn{2}{|c|}{ Level of Detail } \\
\hline & Overview & 3D & $4 \mathrm{D}$ & $5 \mathrm{D}$ & $6 \mathrm{D}$ & LOD & LOI \\
\hline 0 & $\begin{array}{c}\text { Competition conceptual } \\
\text { design }\end{array}$ & \multirow[b]{2}{*}{ Not applicable } & & & & & \\
\hline & $\begin{array}{l}\text { As stipulated in the } \\
\text { competition } \\
\text { requirements }\end{array}$ & & & & & & \\
\hline \multirow[t]{2}{*}{1} & $\begin{array}{l}\text { Multi-specialization } \\
\text { proposal }\end{array}$ & \multirow{2}{*}{$\begin{array}{l}\text { Architecture, } \\
\text { compliance with } \\
\text { assumptions and } \\
\text { optimization of the } \\
\text { functional program, } \\
\text { specification of essential } \\
\text { requirements, impact of } \\
\text { the building on the } \\
\text { surroundings }\end{array}$} & \multirow[b]{2}{*}{$\begin{array}{l}\text { Initial design } \\
\text { work } \\
\text { schedule }\end{array}$} & \multirow[b]{2}{*}{$\begin{array}{c}\text { Approximate } \\
\text { cost } \\
\text { estimates }\end{array}$} & & \multirow[b]{2}{*}{3} & \multirow[b]{2}{*}{3} \\
\hline & $\begin{array}{l}\text { Building massing and its } \\
\text { location, general interior } \\
\text { layout with area and } \\
\text { volume of each zone } \\
\text { specified }\end{array}$ & & & & & & \\
\hline \multirow[t]{2}{*}{2} & $\begin{array}{l}\text { Multi-specialization } \\
\text { technical design }\end{array}$ & \multirow[b]{2}{*}{$\begin{array}{l}\text { Inter-specialization } \\
\text { coordination, clash } \\
\text { analysis, analysis of the } \\
\text { impact of proposed } \\
\text { solutions on building } \\
\text { maintenance costs }\end{array}$} & \multirow[b]{2}{*}{$\begin{array}{l}\text { Design } \\
\text { schedule }\end{array}$} & \multirow[b]{2}{*}{$\begin{array}{l}\text { Bill of } \\
\text { quantities } \\
\text { and initial } \\
\text { bill of costs }\end{array}$} & \multirow[b]{2}{*}{$\begin{array}{l}\text { Initial energy } \\
\text { consumption } \\
\text { analysis }\end{array}$} & \multirow[b]{2}{*}{4} & \multirow[b]{2}{*}{4} \\
\hline & $\begin{array}{l}\text { In accordance with the } \\
\text { requirements for and the } \\
\text { purpose of the technical } \\
\text { design. BIM model and } \\
\text { specialist models with } \\
\text { an enhanced level of } \\
\text { detail that allows for } \\
\text { achieving BIM goals } \\
\text { specified for this stage. }\end{array}$ & & & & & & \\
\hline \multirow[t]{2}{*}{3} & $\begin{array}{l}\text { Multi-specialization } \\
\text { detailed design }\end{array}$ & \multirow[b]{2}{*}{$\begin{array}{l}\text { Inter-specialization } \\
\text { coordination, clash } \\
\text { analysis, analysis of the } \\
\text { impact of solutions } \\
\text { featured in the building } \\
\text { on maintenance costs }\end{array}$} & \multirow[b]{2}{*}{$\begin{array}{c}\text { Design } \\
\text { schedule } \\
\text { verification }\end{array}$} & & \multirow[b]{2}{*}{$\begin{array}{l}\text { Energy } \\
\text { consumption } \\
\text { analysis, } \\
\text { water } \\
\text { management }\end{array}$} & \multirow[b]{2}{*}{5} & \\
\hline & $\begin{array}{l}\text { In accordance with the } \\
\text { requirements for and the } \\
\text { purpose of the detailed } \\
\text { design. BIM model and } \\
\text { specialist models with } \\
\text { an enhanced level of } \\
\text { detail that allows for } \\
\text { achieving BIM goals } \\
\text { specified for this stage. }\end{array}$ & & & $\begin{array}{l}\text { Detailed bill } \\
\text { of costs }\end{array}$ & & & 5 \\
\hline
\end{tabular}

As model components should include a time element, it is possible to apply 4D BIM by creating schedules that can be modified along with the real-world progress of construction during a later phase and account for any delays. The 5D model that accounts for impact on costs can be built by grouping model components for easy use in cost assessment software, thus creating various cost-based alternatives and allowing for cost control (as the projects concern public commissions, the price of an element is an average of the element price in a given class/type). An EIR can also indicate that elements that actively and passively affect energy consumption should include data for the performance of energy and comfort of use analyses, such as water demand analysis (6D models). The acoustics model for the Music Center was to also enable acoustics analyses, following detailed stipulated in the "Acoustics guidelines" contract appendix. 


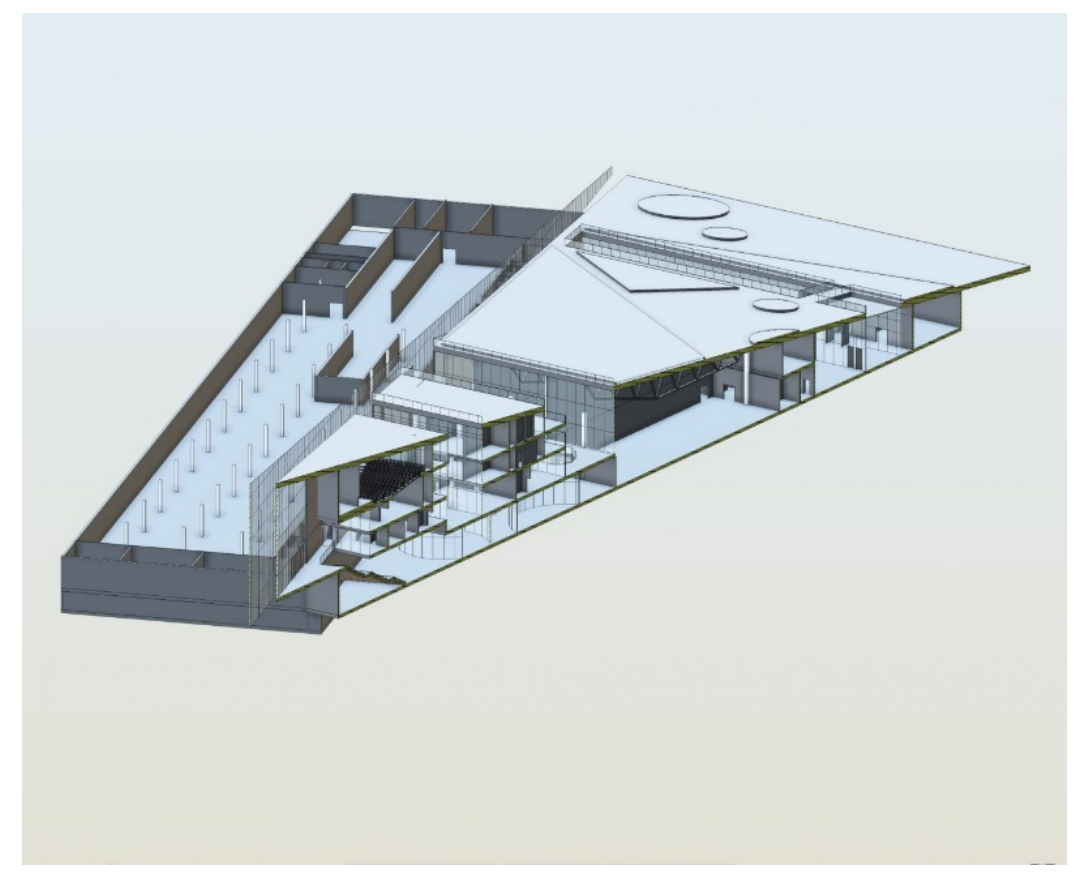

Figure 3. BIM model of the Cogiteon Lesser Poland Science Center. Source: [45].

The EIRs for the LPSC and KMC also stipulated the necessity of dividing the massing into zones to make it easier to export data to the COBie format (starting point for 7D BIM models). The necessity to design elements along with a unique COBie identifier, or a different one proposed by the designer, thus allowing linking them with an external database was also specified as mandatory in the CRS EIR.

In its final points, the EIR for the LPSC indicated a representative of the Ordering Party as responsible for schedule execution and data quality control, while the EIR for the KMC appointed a representative of the designer to this role. It specified that the documentation given to the developer would be subjected to an internal inspection by the contractor that was to follow the requirements and goals stipulated in the contract (including the EIR), after the removal of any clashes, save for those that required developer approval. In the CRS EIR, the BIM coordinator was to be a person from the Ordering Party's team, responsible for coordinating data deliveries and clash detection. Based on the data submitted to the developer, this person was to verify project advancement, adherence to contractual guidelines, the model updating and access privileges of relevant project participants and the sharing and transfer of data by the designer, along with comments and clashes. Based on these data, the developer was to make decisions about approving a given project stage. Naturally, the designer was also responsible for internal coordination and the transfer of models compliant with the contract's provisions.

\section{Conclusions}

The Employer's Information Requirements (Exchange Information Requirement in [37]) with the investor's guidelines is an important document of the investment process [34,41,42]. Its proper preparation can avoid disappointment with the end result [49]. It can also use information throughout this entire life cycle [24,34].

By selecting public orders concerning construction projects to be executed using BIM, intending to present key aspects discussed in Employer's Information Requirements in the widest possible manner, three projects were selected for study: the EIRs that acted as guidelines for design firms for the Copernican Revolution Studio in Warsaw, the Lesser Poland Science Center-also called Cogiteon—and the Krakow Music Center. The Employer's Information Requirements documents analyzed in this paper show similarities in many areas. Among the bidding procedures aimed at selecting a design firm to prepare a 
complete design documentation, the first concerned the construction of the Copernican Revolution Studio in Warsaw. It is probably for this reason that it was less detailed than the other two documents. The next construction project concerned the Lesser Poland Science Center, which is also called Cogiteon. As these buildings had a similar function, and both were public commissions and there had been instances of inter-developer communication, the second EIR was found to be more detailed. The last of the analyzed EIRs to be published was for the Krakow Music Center. The EIRs for the LPSC and KMC were very similar as these projects had the same developer, the Office of the Marshall of the Lesser Poland Voivodeship, and little time had passed between their publication. The lack of state guidelines at the time of the EIRs' publication was an essential factor that affected their content. During the preparation of the bidding documentation, the now-available international standard ISO 19650 [37] had not been released yet. The EIRs' publishers thus partially referenced British guidelines and provided space for proposals to have them changed by the project contractors, who could propose other guidelines and definitions, which, after the approval of the developer, would be included in the BIM Execution Plan, a contract appendix abbreviated as BEP, which would provide a more extensive overview of BIM-related issues. However, it should be noted that EIR guidelines also showed similarity with Polish proposals featured in BIM Standard PL [47].

The developer's requirements were divided into three main areas: technical, management and strategic, following the Polish standard [47]. The issues included in each area were listed. The areas that are most significant or the most difficult in preparing an EIR document were developed further; for instance, in the technical area, they included model exportability into an IFC format, requirements for the Common Data Exchange platform, data export to a specific format such as COBie, used during the use stage, defining levels of detail. In the field of management, this included a description of inter-stakeholder communication standards and stakeholder roles and duties, and model coordination reporting procedures; in the strategic area, it was defined which models, analyses, schedules and bills of costs should be delivered and when. A critical assessment was performed and different solutions were proposed while citing the literature. The guidelines analyzed here can be improved, e.g., by extending the section on the level of detail (which is why guidelines that can be used in the future were prepared and presented), component elements concerning prices and qualifications, so that cost schedules can be easier to generate, as well as information related to facility management, which would encourage cooperation with the facility manager during the design stage. Further research will analyze Employer's Information Requirements documents prepared for other construction projects.

Modern technologies such as BIM develop rapidly and it is beneficial to continually follow their advancement, in addition to new literature and relevant guidelines. Contracts executed by public institutions using BIM can encourage people to apply the insight gained from their completion. Numerous items such as design documentation or guidelines concerning project participants, are published and are a source of information for companies that are just starting to apply BIM.

Author Contributions: Conceptualization, K.Z. and E.M.-K.; methodology, K.Z. and E.M.-K.; validation, K.Z. and E.M.-K.; formal analysis, K.Z. and E.M.-K.; investigation, K.Z. and E.M.-K.; resources, K.Z. and E.M.-K.; data curation, K.Z. and E.M.-K.; writing-original draft preparation, K.Z. and E.M.-K.; writing-review and editing, K.Z. and E.M.-K.; visualization, K.Z. and E.M.-K.; supervision, K.Z. and E.M.-K.; project administration, K.Z. and E.M.-K.. All authors have read and agreed to the published version of the manuscript.

Funding: Not applicable.

Institutional Review Board Statement: Not applicable.

Informed Consent Statement: Not applicable.

Data Availability Statement: Not applicable.

Conflicts of Interest: The authors declare no conflict of interest. 


\section{Appendix A}

Table A1. Level of detail definitions from the EIR appendices for the Lesser Poland Science Center and the Krakow Music Center, formulated based on British guidelines.

\begin{tabular}{|c|c|c|}
\hline LOD & Object Level of Detail & Data Overview \\
\hline 1 & Symbolic & $\begin{array}{l}\text { The object is represented by a placeholder symbol that does not need to be } \\
\text { adapted to scale and no dimensions need to be provided. This level is often } \\
\text { used for electrical symbols, which are always } 2 \mathrm{D} \text { symbols. Buildings are } \\
\text { modeled as simple 2D or 3D objects (cylinders, circles, rectangles, cuboids) } \\
\text { placed in rough approximation on the terrain model. }\end{array}$ \\
\hline 2 & Conceptual & $\begin{array}{l}\text { Simple replacement symbols with minimum level of details that allow the } \\
\text { identification of a given type, e.g., any type of window. A rough estimate } \\
\text { of dimensions. A generalized material type, such as "white," "tiles," } \\
\text { "concrete." Buildings modeled as 3D objects with the inclusion of stories. } \\
\text { Essential furnishing elements in the form of independent objects such as } \\
\text { transformer stations or central HVAC units modelled as simple 3D objects } \\
\text { (cylinders, cuboids). The model allows for a rough assessment of volume, } \\
\text { area or cost, based on indicators. }\end{array}$ \\
\hline 3 & General & $\begin{array}{l}\text { A general model, with a level of detail that allows the identification of } \\
\text { object types and materials. Dimensions can be close to actual ones, yet key } \\
\text { dimensions should be accurate. The model includes the orientation of the } \\
\text { building and its elements in space. It allows for assessing approximate area } \\
\text { or volume, and the preparation of approximate bill of quantities. }\end{array}$ \\
\hline 4 & Detailed & $\begin{array}{l}\text { Model of a building that reflects its dimensions, that allows for identifying } \\
\text { the type of object or material. A model that includes both "built" and } \\
\text { premade elements, compliant with design assumptions and the final } \\
\text { version of the design stage. A model that can be used to assess costs and } \\
\text { prepare bids. A model that allows for detecting clashes between each } \\
\text { specialization's elements. }\end{array}$ \\
\hline 5 & Construction phase & $\begin{array}{l}\text { Precise and accurate model of the building that includes information } \\
\text { necessary to build it, e.g., its geometry, manufacturer and subcontractor } \\
\text { data. Used only when an accurate 3D view is necessary due to essential } \\
\text { details. A model used at the construction site and for prefabrication. }\end{array}$ \\
\hline 6 & Post-completion & $\begin{array}{c}\text { The model should accurately reflect the real-world state of the completed } \\
\text { building. It must include all revisions and changes relative to the original } \\
\text { design. }\end{array}$ \\
\hline 7 & Occupancy/management & $\begin{array}{l}\text { A model enhanced to include data on the building's management and } \\
\text { occupancy. }\end{array}$ \\
\hline
\end{tabular}

\section{References}

1. Vanlande, R.; Nicolle, C.; Cruz, C. IFC and building lifecycle management. Autom. Constr. 2008, 18, 70-78. [CrossRef]

2. Jernigan, F. BIG BIM Little Bim: The Practical Approach to Building Information Modeling Integrated Practice Done the Right Way; 4Site Press: Salisbury, MD, USA, 2007.

3. Yan, H.; Demian, P. Benefits and Barriers of Building Information Modeling. In Proceedings of the 12th International Conference on Computing in Civil and Building Engineering, Beijing, China, 16-18 October 2008.

4. Hamada, H.; Haron, A.; Zakiria, Z.; Humada, A. Benefits and Barriers of BIM Adoption in the Iraqi Construction Firms. Int. J. Innov. Res. Adv. Eng. 2016, 3, 76-84.

5. Hasan, A.; Rasheed, S. The Benefits of Challenges to implement 5D BIM in construction industry. Civ. Eng. J. 2019, 5, 412-421. [CrossRef]

6. Azhar, S. Building Information Modeling (BIM): Trends, Benefits, Risks, and Challenges for the AEC Industry. Leadersh. Manag. Eng. 2011, 11, 241-252. [CrossRef]

7. Rajendran, P.; Gomez, C.P. Implementing BIM for Waste Minimalsation in the Construction Industry: A Literature Review. In Proceedings of the 2nd International Conference on Management Proceeding, Mukim Kedawang, Daerah Langkawi, Malaysia, 11-12 June 2012. 
8. Gerbert, P.; Castagnino, S.; Rothballer, C.; Renz, A.; Filitz, R. Digital in Engineering and Construction: The Transformative Power of Buliding Information Modeling; Boston Consulting Group: Boston, MA, USA, 2016; Available online: https://www.bcg.com/ publications / 2016/engineered-products-infrastructure-digital-transformative-power-building-information-modeling (accessed on 10 October 2021).

9. Smith, P. BIM implementation-Global strategies. Procedia Eng. 2014, 85, 482-492. [CrossRef]

10. Jung, W.; Lee, G. The Status of BIM Adoption on Six Continents. World Acad. Sci. Eng. Technol. Int. J. Civ. Environ. Eng. 2015, 9, 512-516.

11. Arrotéia, A.V.; Freitas, R.C.; Melhado, S.B. Barriers to BIM Adoption in Brazil. Front. Built Environ. 2021, 7, 16. [CrossRef]

12. Al-Hammadi, M.A.; Tian, W. Challenges and Barriers of Building Information Modeling Adoption in the Saudi Arabian Construction Industry. Open Constr. Build. Technol. J. 2020, 14, 98-110. [CrossRef]

13. Aitbayeva, D.; Hossain, A. Building Information Model (BIM) Implementation. J. Eng. Res. Rep. 2020, 14, 13-24.

14. Bouhmoud, H.; Loudyi, D. Building Information Modeling BIM barriers in Africa versus global challenges. In Proceedings of the 6th IEEE Congress on Information Science and Technology, Essaouira, Morocco, 12-18 December 2020.

15. Zima, K.; Mitera-Kiełbasa, E. BIM w zamówieniach publicznych w Polsce ang. BIM in public procurement in Poland. Inżynier Budownictwa 2018, 11, 76-80.

16. Kacprzyk, Z. Projektowanie w Procesie BIM ang. Designing in the BIM Process; Oficyna Wydawnicza Politechniki Warszawskiej: Warsaw, Poland, 2020.

17. Jinming, L.; Kereshmeh, A.; Nianping, L.; Jinqing, P.; Zhibin, W.; Haijiao, C. A review for presenting building information modeling education and research in China. J. Clean. Prod. 2020, 259, 120885.

18. Sánchez, A.; Gonzalez-Gaya, C.; Zulueta, P.; Sampaio, Z. Introduction of building information modeling in industrial engineering eduction: Students' perception. Appl. Sci. 2019, 9, 3287. [CrossRef]

19. Šadauskienè, J.; Pupeikis, D. Review of BIM implementation in Higher Education. J. Sustain. Archit. Civ. Eng. 2018, $22,99-109$.

20. Adamu, Z.; Thorpe, T. How universities are teaching bim: A review and case study from the UK. J. Inf. Technol. Constr. 2016, 21, 119-139.

21. Waszkiewicz, M. Projekt edukacyjny BIM w nowej koncepcji kształcenia Wydziału Zarządzania Politechniki Warszawskiej. BIM educational project in a new education concept at the Faculty of Management of Warsaw University of Technology. Studies and Works of College of Management and Finance. Zeszyt Naukowy 2018, 159, 207-227.

22. Besné, A.; Pérez, M.Á.; Necchi, S.; Peña, E.; Fonseca, D.; Navarro, I.; Redondo, E. A Systematic Review of Current Strategies and Methods for BIM Implementation in the Academic Field. Appl. Sci. 2021, 11, 5530. [CrossRef]

23. Wang, L.; Huang, M.; Zhang, X.; Jin, R.; Yang, T. Review of BIM Adoption in the Higher Education of AEC Disciplines. J. Civ. Eng. Educ. 2020, 146, 06020001. [CrossRef]

24. Abanda, F.H.; Vidalakis, A.H.; Oti, A.H.; Tah, J.H.M. A Critical analysis of Building Information Modelling systems used in construction Projects. Adv. Eng. Softw. 2015, 90, 183-201. [CrossRef]

25. Eldeep, A.M.; Farag, M.A.M.; Abd El-hafez, L.M. Using BIM as a lean management tool in construction process-A case study. Ain Shams Eng. J. 2021. [CrossRef]

26. De Geatani, C.I.; Mert, M.; Migliaccio, F. Interoperability Analyses of BIM Platforms for Construction Management. Appl. Sci. 2020, 10, 4437. [CrossRef]

27. Klusmann, B.; Meng, Z.; Kremer, N.; Meins-Becker, A.; Helmus, M. BIM Based Information Delivery Controlling System. In Proceedings of the 37th International Symposium on Automation and Robotics in Construction ISARC 2020, Aarhus, Denmark, 27-28 October 2020.

28. Radl, J.; Kaiser, J. Benefits of Implementation of Common Data Environment (CDE) into Construction Projects. IOP Conf. Ser. Mater. Sci. Eng. 2019, 471, 022021. [CrossRef]

29. Nascimento, D.; Caiado, R.; Tortorella, G.; Ivson, P.; Meiriño, M. Digital Obeya Room: Exploring the synergies between BIM and lean for visual construction management. Innov. Infrastruct. Solut. 2018, 3, 19. [CrossRef]

30. Xu, X.; Ma, L.; Ding, L. A framework for BIM-enabled Life-cycle information management of construction project. Int. J. Adv. Robot. Syst. 2014, 11, 126. [CrossRef]

31. Schehzad, H.M.F.; Ibrahim, R.B.; Yusof, A.F.; Khaidzir, K.A.M.; Iqbal, M.; Razzaq, S. The role of interoperability dimensions in building in building information modelling. Comput. Ind. 2021, 129, 103444. [CrossRef]

32. Pruskova, K.; Kaiser, J. Implementation of BIM technology into the design process using the scheme of BIM Execution Plan. IOP Conf. Ser. Mater. Sci. Eng. 2019, 471, 022019. [CrossRef]

33. Boton, C.; Forgues, D. Practices and processes in BIM projects: An exploratory case study. Adv. Civ. Eng. 2018, 2018, 1-12. [CrossRef]

34. Ashworth, S.; Tucker, M.; Druhmann, C. Employer's Information Requirements (EIR): A BIM case study to meet client and facility manager needs. In Proceedings of the 16th EuroFM Research Symposium, Madrid, Spain, 25-28 April 2017.

35. Ganah, A.; Lea, G. A global analysis of BIM standards across the globe: A critical review. J. Proj. Manag. Pract. 2021, 1, 52-60.

36. Lee, G.; Borrmann, A. BIM policy and management. Constr. Manag. Econ. 2020, 38, 413-419. [CrossRef]

37. ISO 19650-1:2018. Organization and Digitization of Information about Buildings and Civil Engineering Works, Including Building Information Modelling (BIM)_Information Management Using Building Information Modelling_Part 1: Concepts and Principles; International Organization for Standardization: Geneva, Switzerland, 2018. 
38. ISO 55000:2014. Asset Management-Overview, Principles and Terminology; International Organization for Standardization: Geneva, Switzerland, 2014.

39. ISO 21500:2021. Project, Programme and Portfolio Management-Context and Concepts; International Organization for Standardization: Geneva, Switzerland, 2021.

40. Zima, K.; Mitera-Kiełbasa, E. Proposal of levels of detail LOD in building projects implementing BIM. In Advances and Trends in Engineering Sciences and Technologies III, Proceedings of the 3rd International Conference on Engineering Sciences and Technologies (ESaT 2018), Tatranské Matliare, Slovak Republic, 12-14 September 2018; CRC Press/ Balkema Taylor\&Francis Group: London, UK, 2019.

41. Munir, M.; Kiviniemi, A.; Jones, S.; Finnegan, S. BIM-based operational information requirements for asset owners. Archit. Eng. Des. Manag. 2019, 16, 100-104. [CrossRef]

42. Dakhil, A.J.; Underwood, J.; Al Shawi, M. Critical success competencies for the BIM implementation process: UK construction clients. J. Inf. Technol. Constr. 2019, 24, 80-94.

43. The Public Information Bulletin. Available online: https:/ / www.bip.krakow.pl/ (accessed on 6 November 2021).

44. Copernicus Science Centre. Available online: https://www.kopernik.org.pl/ (accessed on 6 November 2021).

45. Lesser Poland Science Center Cogiteon. Available online: https://cogiteon.pl/ (accessed on 6 November 2021).

46. Krakow Music Center. Available online: http:/ /www.centrummuzyki.malopolska.pl (accessed on 28 October 2021).

47. BIM Standard PL. Projekt Zasad Przygotowania i Realizacji Inwestycji Kubaturowych w Polsce Zgodny z Normą PN-EN ISO 19650 i Krajowym Prawem Budowlanym ang. Project of Rules for Preparation and Implementation of Investments in Poland in Accordance with the PN-EN ISO 19650 Standard and the National Construction Law. 2020. Available online: https: / / www.gov.pl/attachment/9a5b41e7-dcc1-4d1c-aa9e-4174c008df82 (accessed on 6 November 2021).

48. NBS—Global Leading Technology Platform. Available online: https://www.thenbs.com/ (accessed on 6 November 2021).

49. Zima, K.; Mitera-Kiełbasa, E. Poziom szczegółowości LOD w BIM na przykładach ściany z betonu komórkowego i ściany trójwarstwowej szczelinowej ang. LOD level of detail in BIM on the examples of aerated concrete wall and three-layer diaphragm wall. In Proceedings of the Wybrane problemy naukowe budownictwa: 65. Konferencja Naukowa Komitetu Inżynierii Ladowej i Wodnej PAN oraz Komitetu Nauki PZITB, Krynica-Zdrój, Poland, 15-20 September 2020; Wydawnictwo Naukowe PWN: Warszawa, Poland, 2020; pp. 139-147.

50. BSI. Institution. PAS-1192-2-2013 Specification for Information Management for the Capital'delivery Phase of Construction Projects Using Building Information Modelling; BSI Standards Limited: London, UK, 2013.

51. BIMForum. Level of Development Specification for Building Information Models and Data, Licensed under the Creative Commons Attribution-NonCommercial-NoDerivatives. 2020. Available online: https://bimforum.org/resources/Documents/ BIMForum_LOD-Spec-2020.zip (accessed on 6 November 2021).

52. PN-EN ISO 19650-1:2019-02. Organization and Digitization of Information about Buildings and Civil Engineering Works, Including Building Information Modelling (BIM)_Information Management Using Building Information Modelling_Part 1: Concepts and Principles; Polish Normalizing Committee: Warsaw, Poland, 2019.

53. Commissioned by the Polish Ministry of Infrastructure Powiazanie Wymagań Technicznych Dotyczacych Drogowych Obiektów Inżynierskich z Technologią BIM. Wzorce i Standardy Rekomendowane Przez Ministra Właściwego ds. Transportu BIM-M-01 ang. Linking Technical Requirements for Road Engineering Structures with BIM Technology. Patterns and Standards Recommended by the Minister Responsible for Transport BIM-M-01; 2021. Available online: http://www.gov.pl/attachment/a8c896b3-f306-4 5a3-b44e-3b54931b0f9b (accessed on 6 November 2021).

54. Commissioned by the Polish Ministry of Development Cyfryzacja Procesu Budowlanego w Polsce. Zarzadzanie Inwestycja Budowlaną w Metodyce BIM-Szablony Dokumentów BIM ang. Digitization of the Construction Process in Poland. Construction Investment Management in BIM Methodology_BIM Document Templates; 2020. Available online: https://www.gov.pl/ attachment/18f9b1bd-a3eb-4c83-af26-258d03a02e18 (accessed on 6 November 2021).

55. Plebankiewicz, E.; Mitera, E. Źródła marnotrawstwa na budowie ang. Wates on construction site. Mater. Bud. Konstr. Technol. Rynek 2016, 6, 184-185. 